\title{
Anti-cancer and Anti-microbial Potential of Nutraceutical Rich Under utilized Herb Portulaca Oleracea from Kashmir Region
}

\author{
Imtiyaz Murtaza $^{1 *}$, Navreen Rashid ${ }^{1}$, Omi Laila ${ }^{1}$, Nisar Ahmad Ganie ${ }^{2}$ \\ and M. Younus Wani ${ }^{2}$ \\ ${ }^{1}$ Biochemistry and Molecular Biotechnology Laboratory, \\ Division of Basic Sciences and Humanities, SKUAST-K, J\&K, India \\ ${ }^{2}$ CoTS, Mirgund, SKUAST-K, J\&K, India \\ *Corresponding author
}

\section{A B S T R A C T}

\begin{abstract}
Portulaca oleracea (commonly known as Nunner in Kashmir) is an underutilized wild vegetable in the Kashmir region. This vegetable is believed to be highly nutritional and quite health beneficial, however, has remained highly unexplored. Therefore, in the current study, the nutraceutical composition as well as antimicrobial and anticancerous potential of wild edible herb Portulaca oleracea (common purslane) was determined in its fresh as well as dried form. The results revealed that dried form comparatively contains higher carbohydrates $(25.1 \pm 0.173 \%)$, crude protein $(19.83 \pm 0.145 \%)$, crude fat $(4.02 \pm 0.011 \%)$, crude fiber $(7.19 \pm 0.017 \%)$, total soluble sugars $(3.56 \pm 0.012 \%)$, reducing sugars $(3.16 \pm 0.012 \%)$ and non-reducing sugars $(0.40 \pm 0.023 \%)$. In addition, Portulacaoleracea proved to be a rich source of calcium $(1366.66 \pm 0.120 \mathrm{mg} / 100 \mathrm{~g})$, magnesium $\quad(943.93 \pm 0.713 \mathrm{mg} / 100 \mathrm{~g})$, sodium $\quad(153.63 \pm 0.145 \mathrm{mg} / 100 \mathrm{~g})$ and iron $(47.66 \pm 0.088 \mathrm{mg} / 100 \mathrm{~g})$ content. The nutraceuticals were also found to be present in appreciable amounts includingtotal phenols $385.96 \pm 0.744 \mathrm{mg} / 100 \mathrm{~g}$, total flavonoids $98.66 \pm 0.120 \mathrm{mg} / 100 \mathrm{~g}$ and total anthocyanins $881.76 \pm 0.088 \mathrm{mg} / 100 \mathrm{~g}$, respectively. The antimicrobial assay demonstrated that $P$. oleracea has great potential to be used as an antimicrobial agent against Staphylococcus aureus and E. coli $(E P E C)$ pathogens. Interestingly, the aqueous extracts of dried P. oleracea exhibited potent dose and time dependent cytotoxic effects against HL-60, MOLT-4 and T47-d cancer cell lines under in vitro conditions. Thus, through this study, we provide a scientific basis for nutraceutical rich Portulaca oleracea from Kashmir valley for its folklore or ethno-medicinal uses, and for its further exploitation as a highly useful alternative strategy for antimicrobial and anti-cancer drug development or as an adjuvant to existing therapies.
\end{abstract}

\section{Introduction}

In the present era, cancer remains a major global health concern, being one of the world's most deadly diseases. Despite significant breakthroughs in the understanding, prevention, and treatment of this disorder, cancer is still the point of concern for the whole world. In 2018 nearly 18.1 million people around the world had cancer and 9.6 million died from the disease. This number will nearly double by 2040, with almost two thirds increase to occur in low and middle income countries (WHO, 2020). 
This alarmingly high rate of mortality among cancer patients is a clear indication of insufficient efficiency of the current available medications and therapies including radiation, chemotherapy and surgery. Now-a-days, in addition to cancer burden, antibiotic resistance has also become a global issue and is recognized by the World Health Organization (WHO) as the greatest threat in the treatment of infectious diseases (WHO, 2020).

Three such infectious diseases have been ranked in top ten causes of death globally, including lower respiratory infections (3.1 million deaths), HIV/AIDS (1.5 million deaths) and tuberculosis (1.3 million deaths) excluding deaths due to recent COVID19 Pandemic. Although, some people are at greater risk than others but no one can completely avoid the risk of such infections especially with antibiotic resistant organisms that are difficult to treat, require costly and sometimes toxic alternatives. Therefore, the need of hour is to continue the search for much safer and more effective chemopreventive anticancerous and antimicrobial agents to combat against such diseases.

Among the different regimes, since the immortal time natural plants or herbs have a long history of curbing oxidative stress related disorders and microbial diseases (Durgawale et al., 2019). Recent, scientific data clearly indicates that the wild plants or herbs in addition to being a rich source of nutrients represent a potent resource of numerous bioactive nutraceuticals for the development of new antibiotics or anticancerous prototypes.

Therefore, the current trend across the globe is shifting towards the use of natural plant products (such as crude plant extracts) or a combination of nutraceuticals as a new source of potent and novel drugs with minimal side effects (Khameneh et al., 2019; Amaral et al., 2019). Various edible wild plants apart from being rich source of nutrients have been reported to possess enormous medicinal potential due to the presence of such bioactive secondary metabolites (Kour et al., 2018). As far as Jammu and Kashmir is concerned, the UT is bestowed with a huge variety of wild edible herbs having immense health promoting potential (Nabi et al., 2017).

One such wild edible vegetable, Portulaca oleracea commonly called as "Nunner" in Kashmiri has recently gained a great deal of attention from nutritionalists worldwide due to its rich nutritional profile and biochemical composition. The dried aerial parts of this plant have been used for the treatment of fever, dysentery, diarrhea, carbuncle, eczema and hematochezia, with a recommended dose of $9-15 \mu \mathrm{g}$ in traditional system of medicines (Chugh et al., 2019).

Though, the plant has been reported to possess several biological activities such as anticancer, antioxidant, anti-inflammatory and immunity enhancing properties, but it is highly unexplored in the UT of J\&K (Tan et al., 2013). Therefore, in the current study the nutraceutical, antimicrobial and anticancerous potential of wild $P$. oleracea from Kashmir region is reported.

\section{Materials and Methods}

\section{Collection of plant sample}

The current investigation was carried out in the Biochemistry and Molecular Biotechnology Laboratory, Division of Basic Sciences and Humanities, SKUAST-K, Shalimar, Kashmir J\&K during the year 201617. The whole plant samples of Portulaca oleracea at their edible growth stage were collected from the open fields of Shalimar campus, SKUAST-K during the month of 
July-August. The collected samples were rinsed thoroughly with distilled water and after draining water either used as such or shade dried, pulverized, and stored in an airtight container. The fresh as well as dried samples were then subjected to further investigations.

\section{Nutritional analysis}

The moisture, ash, crude fat and crude fiber content of Portulaca oleracea samples (dried as well as fresh) were determined by standard sustenance investigation techniques portrayed in the Association of Official Analytical Chemists (AOAC, 2000). The total carbohydrate, total soluble sugars, reducing sugars as well as non-reducing sugars and crude protein were assessed by methods reported in Thimmaiah (1999). For mineral estimation, $P$. oleracaea samples (1gm) were taken in flasks, and $20 \mathrm{ml}$ of di-acid (mixture of nitric acid and per chloric acid, in the ratio of 9:4) added to each flask.

The flasks were kept undisturbed overnight and next day placed on a hot plate (115-118 ${ }^{\circ}$ C) for digestion till a watery transparent aliquot was obtained. The digested samples were filtered and diluted with double distilled water to make final volume upto $50 \mathrm{ml}$, that were ultimately used for estimation of minerals, through atomic absorptionspectroscopy (AAS) (AA 800, Perkin-Elmer Germany). Standardsolutions of each mineral viz., Calcium $(\mathrm{Ca})$, sodium $(\mathrm{Na})$, magnesium $(\mathrm{Mg})$ and iron $(\mathrm{Fe})$ were prepared, calibration curves were drawnfor each element, and minerals determined.

\section{Nutraceutical analysis}

The total phenolic content of $P$. oleracaea samples was determined by modified method of Malick and Singh (1980). The total flavonoids were estimated by Lallianrawna et al., (2013) method and ascorbic acid from fresh leaf samples was assessed by volumetric method of Sadasivam and Theymoli (1987). The $\beta$-carotene content was evaluated by Nagata and Yamashita (1992) method and total anthocyanin content was calculated as reported by Rangana (1997).

\section{Antimicrobial assay}

For antimicrobial assay, $10 \mathrm{~g}$ (dried) of $\mathrm{P}$. oleracea samples (dried) were extracted with sufficient quantity of three selected solvents (i.e. distilled water, ethanol and methanol) by maceration method at room temperature. The extracts were filtered and concentrated at 40 ${ }^{\circ} \mathrm{C}$ using vacuum evaporator. The dried extracts were then scrapped off and transferred to a tarred wide mouth glass container of appropriate size. Nitrogen was blown in the container before capping and the container was weighed to calculate the yield of each crude extract obtained. The crude extracts so obtained were redissolved in their respective solvents (distilled water, ethanol and methanol) and different concentrations $(1 \mathrm{mg} / \mathrm{ml}, 10 \mathrm{mg} / \mathrm{ml}, 20 \mathrm{mg} / \mathrm{ml}$ and $30 \mathrm{mg} / \mathrm{ml})$ of each extract were prepared for determination of their antibacterial activity The test (aqueous, methanolic and ethanolic) extracts were screened for their antibacterial activity against pathogenic bacteria staphylococcus aureus and E. coli (EPEC) using the disc diffusion assay (Miles and Amyes, 1996).

\section{Anticancer activity}

For evaluation of anticancerous potential of $P$. Oleracea, $100 \mathrm{mg}$ of aqueous crude extract was redissolved in $10 \%$ DMSO (Dimethylsulphoxide) and test extract used for further investigations. Three cancer cell lines, HL-60 (Human Promyelocytic leukemia), MOLT-4 (Human- Tlymphoblastic leukemia) and T47-d (ductal 
carcinoma) cultured in RPMI 1640 medium supplemented with $20 \%$ FCS, $2 \mathrm{mmol} / \mathrm{L}$ glutamine, $50 \mathrm{U} / \mathrm{ml}$ penicillin and $50 \mu \mathrm{g} / \mathrm{ml}$ streptomycin were seeded at a density of 10 , 000 cells/well in a 36-well plate, and allowed to attach overnight. The cells were thereafter treated with different concentrations $(100 \mu \mathrm{g}-$ $1000 \mu \mathrm{g})$ of the test extract and allowed to grow for $48 \mathrm{~h}$. The cytotoxic effect of test extracts was determined by MTT cell viability assay. Assuming 100\% viability in control cells, percentage of treated cells viability was calculated as:

Percent of viable cells

$=($ Abs.of treated cells/Abs.of control cells $)$ $\times 100$

\section{Statistical analysis}

Statistical analysis of data generated in this study was performed by using one way analysis of variance (ANOVA), chi-square and correlation tests. The data was analyzed by using comprehensive statistical package SPSS (Version 20) for windows.

\section{Results and Discussion}

Wild medicinal plants are commonly used as vegetables in several parts of the world to maintain health or cure ailments and still represent a milestone for ethno-medicine for the search of new and safer bioactive compounds, and if properly exploited can lead to the development of novel anti-cancerous or antimicrobial therapeutics (Rehman and Adnan, 2018; Ebert et al., 2014; Conti et al., 2019).

$P$. oleracea a wild medicinal herb has nowadays gained a great deal of attention from nutrionalists and biochemists worldwide, due to its marked nutritional and medicinal potential (Khanam et al., 2019; Chugh et al., 2019).
To best of our knowledge, there is scant data available on nutritional and nutraceutical properties of unexplored P. oleracea from Kashmir region. Therefore, the current investigation was carried out to evaluate the nutraceutical, anti-microbial and anticancerous potential of Portulaca oleracea for its further exploitation as anti-microbial and anti-cancerous agent.

In the present era, there has been much concern to diversify the agriculture system through exploring the possibilities of traditional/underutilized plant resources and promote their utilization as alternate nutritive food crops (Mango et al., 2018). In view of this, in the current study the nutritional profiling of Portulaca oleracea revealed that there exists a great deal of variation in the nutritional composition of fresh and dried samples, with dried form exhibiting much more nutritional superiority (Table 1). In this study, the moisture content of fresh Portulaca oleracea was observed to be $90.70 \pm 0.012 \%$, and on drying it got reduced to $8.06 \pm 0.088 \%$ ( $82 \%$ decrease).

The ash content of fresh Portulaca oleracea was found to be $2.02 \pm 0.009 \%$ and increased $(60 \%)$ to $5.16 \pm 0.145 \%$ on drying. The total carbohydrate content of fresh $P$. oleracea was observed to be $3.2 \pm 0.058 \%$ that increased $(21.9 \%)$ to $25.1 \pm 0.173 \%$ on drying. The fresh $P$. oleracea was also found to contain $1.80 \pm 0.009 \%, 1.72 \pm 0.020 \%$ and $0.08 \pm 0.015 \%$ total sugars, reducing sugars and nonreducing sugars, respectively with an increase of $1.76 \%, 1.44 \%$ and $0.32 \%$ on drying.

The crude protein content of dried $P$. oleracea was found to be $19.83 \pm 0.145 \%$ that was $17.68 \%$ higher than fresh samples $(2.15 \pm 0.009 \%)$. Similar trend was also found for crude fat content that increased to $4.02 \pm 0.011 \%$ on drying. Likewise, crude fiber content of dried $P$. oleracea was found to be 
6.98\% higher as compared to fresh $P$. oleracea. These results thus indicate an exceptionally high nutritional value of Portulaca oleracea in its dried form. These results are in strong agreement with the previous reports of Abbasi et al., 2015, AbdEL-Aziz et al., 2014 and EL-Hadidy et al., 2014. The high nutritional value of this crop indicates that it should be recommended as alternate source of diet and can play a beneficial role to human health, especially for the treatment of nutritional deficiencies.

Mineral elements play numerous beneficial roles due to their direct or indirect effects in human metabolism. Their deficiencies or insufficient intake can leads to several dysfunctions and diseases in humans. Studies have indicated widespread occurrence of deficiencies for mineral elements such as anaemia for iron and osteoporosis for calcium in most developing countries as well as developed world (Gonmei and Toteja, 2018). Thus, it is necessary to screen the foods rich in such micronutrients and incorporate such crops in our diets to prevent the occurrence of their deficiencies especially in poor sections of societies.

Therefore, in the current study, the mineral profiling (in terms of calcium, iron, magnesium, sodium) of fresh as well as dried $P$. oleracea was also performed and was found to be quite variable (Table 2). The fresh $P$. oleracea was found to contain $2.30 \pm 0.009$ $\mathrm{mg} / 100 \mathrm{~g}$ iron, $50.06 \pm 0.088 \mathrm{mg} / 100 \mathrm{~g}$ sodium, $68.40 \pm 0.153 \mathrm{mg} / 100 \mathrm{~g}$ calcium and $65.30 \pm 0.058 \mathrm{mg} / 100 \mathrm{~g}$ magnesium. Interestingly, the subsequent mineral content of dried samples increased drastically to $47.66 \pm 0.088 \mathrm{mg} / 100 \mathrm{~g}$ in case of iron, $153.63 \pm 0.145 \quad \mathrm{mg} / 100 \mathrm{~g}, \quad 1366.66 \pm 0.120$ $\mathrm{mg} / 100 \mathrm{~g}$ and $943.93 \pm 0.713 \mathrm{mg} / .100 \mathrm{~g}$ for sodium, calcium and magnesium respectively. These results clearly indicated that dried $P$. oleracea possesses higher concentration of these vital minerals than fresh samples. The results of this study are in accordance with the earlier findings that report an increase in mineral contents of leaves after shade-drying (El-Hadidy et al., 2014, USDA national nutrient data, 2016; Joshi \& Mehta, 2010).

Wild plants are reported to be rich source of bioactive compounds or secondary metabolites that can act either individually or synergistically to maintain health and combat against various oxidative stress related diseases (Fatima et al., 2020). There is a renewed interest to find new and safe antioxidant agents from natural sources including plant foods. In addition to phenols, plants have been reported to contain different levels of numerous antioxidants.

In this study it was observed that there exists a significant variation in the concentration of various bioactive nutraceutical constituents (in terms of total phenols, total flavonoids, $\beta$ carotene, ascorbic acid and anthocyanins) among the fresh and dried $P$. oleracea samples. As far as phenolic compounds are concerned, they are antimicrobial agents and found ubiquitously in these plant-based foods. Their dietary intake have been described to greatly lower the incidence of various chronic degenerative diseases, such as cancer, diabetes etc and thus the exploitation of foods rich in such phenolics will be quite beneficial (Showkat et al., 2020).

Extensive research studies on functioning and role of polyphenols, their dietary sources and health beneficial properties are being explored aggressively in today's world. As evident from table 3, the total phenol content of fresh $P$. oleracea was found to be $131.46 \pm 0.260$ $\mathrm{mg} / 100 \mathrm{~g}$, that got increased to $385.96 \pm 0.744$ $\mathrm{mg} / 100 \mathrm{~g}$ on drying, and thus indicated almost $65.9 \%$ increase in this constituent on drying. The total phenolic content of fresh $P$. oleracea observed in this study lies in parallel 
to the values reported by Lim and Quah (2007) and are slightly lower as reported by El Kashef et al., (2018). However in dried sample, it was observed that there exists a significant increase $(\mathrm{p} \leq 0.01)$ in total phenolic content $(385.96 \pm 0.744 \mathrm{mg} / 100 \mathrm{~g})$ that is in close proximity to the findings of Abd-ELAziz et al., (2014), but lower than as reported by Dugawale et al., (2019). Polyphenols actually represents a diverse group of compounds and among them, flavonoids are widely distributed and are present in most plant tissues.

In humans, several health beneficial properties of dietary flavonoids are recognized for their anti-oxidant, anti-diabetic and anti-proliferative effects which may protect body from various oxidative stress related diseases (Panche et al., 2016). Flavonoids of underutilized crops including Portulaca oleracea have been negligibly identified or studied.

Therefore considering their diverse role, in the present investigation, the total flavonoid content of fresh samples of $P$. oleracea was found to be $6.05 \pm 0.020 \mathrm{mg} / 100 \mathrm{~g}$ that got increased to $98.66 \pm 0.120 \mathrm{mg} / 100 \mathrm{~g}$ on drying and represent almost $93.8 \%$ increase on drying. These values obtained are much lower as reported by Silva and Carvalho (2014) in P.oleracea plant parts from two different locations in Portugal.

However, these finding are in contradiction to findings of Youssef and Moktar (2014) who suggest decrease in total flavonoid content on drying. Yet another sub group of phenols, anthocyanins are water soluble vacuolar pigments that may appear red, blue or purple depending upon $\mathrm{pH}$. They are responsible for the coloration in flowers and have strong antioxidant role against reactive oxygen species (Qiu et al., 2016). The anthocyanin content of dried $P$. oleracea
$(881.76 \pm 0.088 \mathrm{mg} / 100 \mathrm{~g})$ was also observed to be almost $68.8 \%$ higher as compared to fresh P. oleracea $(274.83 \pm 0.176 \mathrm{mg} / 100 \mathrm{~g})$ (Silva and Carvalho, 2014). Ascorbic acid is the main compound contributing to antioxidant activity of green leaves and fruits (Khan et al., 2011).

Similarly, $\beta$-carotene (pro-vitamin A) is an essential nutrient with a number of health promoting effects involved in the regulation and promotion of growth and differentiation of many cells, especially in the eyes and lungs (Olsen et al., 2015). It was observed that $\beta$ carotene and ascorbic acid content of dried $P$. oleracea got drastically decreased on drying. The dried samples contain only $14.63 \pm 0.294 \mathrm{mg} / 100 \mathrm{~g} \quad \beta$-carotene and $19.60 \pm 0.115 \mathrm{mg} / 100 \mathrm{~g}$ ascorbic acid content as compared to fresh $P$. oleracea that contain $17.04 \pm 0.026 \mathrm{mg} / 100 \mathrm{~g}$ and $23.66 \pm 0.120 \mathrm{mg} /$ $100 \mathrm{~g}$ respectively.

These results indicated almost $14.1 \%$ decrease in $\beta$-carotene content and $17.1 \%$ decrease in ascorbic acid on drying $P$. oleracea samples. These results are opposed by the findings of Joshi \& Mehta, (2010) who reported higher retention of $\beta$-carotene on shade drying of drumstick leaves. However our results are in strong agreement with the observations of Gupta et al., (2013) who reported only $1-14 \%$ retention of vitamin $C$ and $26-61 \%$ retention of beta carotene on drying as compared to fresh Amaranthus gangetil, Chenopodium album, Centella asiation, Amaranthus tricolor and Trigonella foenumgreecum samples.

Numerous scientific studies have shown that plants have a high potential to synthesize different antimicrobial substances or compounds including phenols and flavonoids which act as plant defence mechanisms and protect them against various abiotic and biotic stresses (Erdem et al., 2015). 
Recently, scientists and pharmaceutical industries have considered the medicinal plants rich in such natural antimicrobial substances as a better choice to protect against broad spectrum antibiotic resistant bacteria.

Therefore, in this study, the antibacterial activities of methanolic, ethanolic and aqueous extracts of $P$. oleracea in terms of zones of growth inhibitions ( $\mathrm{mm}$ ) were evaluated against two pathogenic bacteria (staphylococcus aureus and E. coli EPEC) and one reference negative control (E. coli DH5- $\alpha$ ). The common antibiotic Kanamycin $(20 \mu \mathrm{g} / \mathrm{ml})$ was used as a positive control for extracts.

As shown in figure 1, both fresh and dried extracts of $P$. oleracea demonstrated antimicrobial activity against the test bacterial strains in a dose dependant manner. However, the dried $P$. oleracea extracts proved to be more potent than fresh $P$. oleracea extracts may be due to high concentration of nutraceuticals. Among the different solvents used, the ethanolic extract of dried $P$. oleracea was found to be the most potent antimicrobial extract (Figure $1 \mathrm{~A} \& 1 \mathrm{~B}$ ).

The non-pathogenic E.coli (DH5- $\alpha$ ) was the most susceptible bacteria to the extract treatments followed by E.coli EPEC and S.aureus. The order of antimicrobial potency demonstrated that ethanolic extracts are most potent and the aqueous the least. It is suggested that such plant extracts have a great potential to be exploited against pathogenic microbes for development of antimicrobial agent in ethnomedicine (Peng et al., 2014; Bakkiyaraj et al., 2011; Wasnik and Tumane, 2014; Lodankar and Nayaka, 2011; Dhole, 2011).

Exploitation of plants rich in bioactive nutraceutical based constituents and their inclusion in our daily diet have been found to be quite beneficial for cancer prevention and treatment, as they have been described to block or inhibit the proliferative integrity of individual cancer cells under cell cultured conditions (Al-Hasawi et al., 2018, Fatima et al., 2020). In the current study, the aqueous extract of dried $P$. oleracea demonstrated remarkable anti proliferative potential against three cancer cell lines (HL-60, MOLT-4 and T47-d) after 24 and 48 hours of treatment (Table 4).

It was found that with an increase in the dose there was higher decline in proliferation and the effect was therefore dose dependent. At $100 \mu \mathrm{g} / \mathrm{ml}$ extract concentration only least cytotoxic effect was observed and most of the

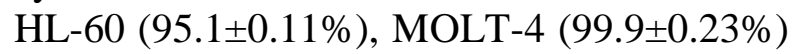
and T47-d $(96.13 \pm 0.17 \%)$ were found to be viable.

However, the viability decreased drastically while increasing the concentration of the extract (Figure 2). The highest concentration of extract used in this study $(1000 \mu \mathrm{g} / \mathrm{ml})$ reduced cell viability to $50.9 \pm 0.54 \%$ in case of HL-60 cell line, $58.5 \pm 0.28 \%$ in MOLT-4 and $60.5 \pm 0.11 \%$ in case of T47-d cells. The $P$. oleracea extract was found to acts in a dose and time dependent manner.

As shown in figure 2, at 700, 800, and 900 $\mu \mathrm{g} / \mathrm{ml}$ concentration, $40 \%$ or more cells died. The $1000 \mu \mathrm{g} / \mathrm{ml}$ of $P$. oleracea extract induced the highest cytotoxicity in HeLa cell linefollowed by MOLT-4 and T47-d cells respectively after 24 and 48 hours $(\mathrm{P}<0.001)$ of treatment.

The results of current study are in strong agreement with the earlier reports that indicate anti-proliferative potential and cytotoxic activity of different extracts of Portulaca oleracea against various cancer cell lines, (Zakaria et al., 2013; Hassan et al., 2014; Chen et al., 2010). 
Table.1 Comparative analysis of proximate composition of fresh and dried Portulaca oleracea

\begin{tabular}{|c|c|c|c|c|c|c|c|c|c|}
\hline Sample & $\begin{array}{l}\text { Moisture } \\
(\%)\end{array}$ & $\operatorname{Ash}(\%)$ & $\begin{array}{l}\text { Total } \\
\text { carbohydrate } \\
(\%)\end{array}$ & $\begin{array}{l}\text { Crude fat } \\
(\%)\end{array}$ & $\begin{array}{l}\text { Crude } \\
\text { protein } \\
(\%)\end{array}$ & $\begin{array}{l}\text { Crude } \\
\text { fiber(\%) }\end{array}$ & $\begin{array}{l}\text { Total } \\
\text { Soluble } \\
\text { sugars } \\
(\%)\end{array}$ & $\begin{array}{l}\text { Redu } \\
\text { cing } \\
\text { Sugars } \\
(\%)\end{array}$ & $\begin{array}{l}\text { Non } \\
\text { Reducing } \\
\text { sugars(\%) }\end{array}$ \\
\hline $\begin{array}{l}\text { Fresh } \\
\text { Portulaca } \\
\text { oleracea }\end{array}$ & $\begin{array}{l}90.70 \\
\pm 0.012\end{array}$ & $\begin{array}{l}2.02 \\
\pm 0.009\end{array}$ & $\begin{array}{l}3.20 \\
\pm 0.058\end{array}$ & $\begin{array}{l}0.19 \\
\pm 0.006\end{array}$ & $\begin{array}{l}2.15 \\
\pm 0.009\end{array}$ & $\begin{array}{l}1.21 \\
\pm 0.012\end{array}$ & $\begin{array}{l}1.80 \\
\pm 0.006\end{array}$ & $\begin{array}{l}1.70 \\
\pm 0.020\end{array}$ & $\begin{array}{l}0.10 \\
\pm 0.015\end{array}$ \\
\hline $\begin{array}{l}\text { Dried } \\
\text { Portulaca } \\
\text { oleracea }\end{array}$ & $\begin{array}{l}8.06 \\
\pm 0.088\end{array}$ & $\begin{array}{l}5.16 \\
\pm 0.145\end{array}$ & $\begin{array}{l}25.10 \\
\pm 0.173\end{array}$ & $\begin{array}{l}4.02 \\
\pm 0.011\end{array}$ & $\begin{array}{l}19.83 \\
\pm 0.145\end{array}$ & $\begin{array}{l}7.19 \\
\pm 0.017\end{array}$ & $\begin{array}{l}3.56 \\
\pm 0.012\end{array}$ & $\begin{array}{l}3.16 \\
\pm 0.012\end{array}$ & $\begin{array}{l}0.40 \\
\pm 0.023\end{array}$ \\
\hline $\mathbf{T}_{\mathrm{cal}}$ & $929.04^{* *}$ & $21.57^{* *}$ & $119.95^{* *}$ & $296.67 * *$ & $287.26^{* *}$ & $287.26^{* *}$ & $136.32 * *$ & $88.18^{* *}$ & $11.55^{* *}$ \\
\hline
\end{tabular}

Results are expressed as mean $\pm \mathrm{SE}$ and are the average of triplicates $* *$ indicates significance level of $\mathrm{p} \leq 0.01$

Table.2 Comparative analysis of mineral content of fresh and dried samples of Portulaca oleracea

\begin{tabular}{|l|c|c|c|}
\hline Parameter & Fresh & Dried & $\mathbf{T}_{\text {cal }}$ \\
\hline Iron & $2.30 \pm 0.009$ & $47.66 \pm 0.088$ & $511.78^{* *}$ \\
\hline Sodium & $50.06 \pm 0.088$ & $153.63 \pm 0.145$ & $609.33^{* *}$ \\
\hline Calcium & $68.40 \pm 0.153$ & $1366.66 \pm 0.120$ & $6679.52^{* *}$ \\
\hline Magnesium & $65.30 \pm 0.058$ & $943.93 \pm 0.713$ & $1228.99 * *$ \\
\hline
\end{tabular}

Results are expressed as mean \pm SE and are the average of triplicates $* *$ indicates significance level of $p \leq 0.01$

Table.3 Comparative analysis of bioactive constituents of Portulaca oleracea

\begin{tabular}{|c|c|c|c|}
\hline Parameter & Fresh & Dried & $\mathbf{T}_{\mathrm{cal}}$ \\
\hline $\begin{array}{l}\text { Total phenols } \\
\text { (mg/100g) }\end{array}$ & $131.46 \pm 0.260$ & $385.96 \pm 0.744$ & $958.07 * *$ \\
\hline $\begin{array}{l}\text { Total flavonoids } \\
\text { (mg/100g) }\end{array}$ & $6.05 \pm 0.020$ & $98.66 \pm 0.120$ & $759.82 * *$ \\
\hline $\begin{array}{r}\text { B-carotene } \\
(\mathrm{mg} / 100 \mathrm{~g})\end{array}$ & $17.04 \pm 0.026$ & $14.63 \pm 0.294$ & $8.141 * *$ \\
\hline $\begin{array}{c}\text { Ascorbic acid } \\
\text { (mg/100g) }\end{array}$ & $23.66 \pm 0.120$ & $19.60 \pm 0.115$ & $24.40 * *$ \\
\hline $\begin{array}{l}\text { Anthocyanins } \\
(\mathrm{mg} / \mathbf{1 0 0 g})\end{array}$ & $274.83 \pm 0.176$ & $881.76 \pm 0.088$ & $3077.71 * *$ \\
\hline
\end{tabular}

Results are expressed as mean $\pm \mathrm{SE}$ and are the average of triplicates $* *$ indicates significance level of $\mathrm{p} \leq 0.01$ 
Table.4 Cytotoxicity activity of dried Portulaca oleracea aqueous extract against MOLT-4, T47-d and Hela cells

\begin{tabular}{|l|c|c|c|}
\hline \multirow{2}{*}{$\begin{array}{l}\text { Extract } \\
\text { Concentration }(\boldsymbol{\mu g} / \mathbf{m l})\end{array}$} & \multicolumn{3}{|c|}{ \% Cell Viability } \\
\cline { 2 - 4 } $\mathbf{1 0 0}$ & $95.1 \pm 0.11$ & $99.9 \pm 0.23$ & $96.13 \pm 0.17$ \\
\hline $\mathbf{2 0 0}$ & $90.1 \pm 0.17$ & $99.8 \pm 0.05$ & $92.06 \pm 0.26$ \\
\hline $\mathbf{3 0 0}$ & $85.3 \pm 0.11$ & $99.2 \pm 0.28$ & $88.13 \pm 0.14$ \\
\hline $\mathbf{4 0 0}$ & $80.5 \pm 0.19$ & $97.5 \pm 0.19$ & $84.20 \pm 0.23$ \\
\hline $\mathbf{5 0 0}$ & $75.6 \pm 0.23$ & $93.7 \pm 0.21$ & $80.16 \pm 0.26$ \\
\hline $\mathbf{6 0 0}$ & $70.7 \pm 0.15$ & $87.4 \pm 0.28$ & $70.06 \pm 0.15$ \\
\hline $\mathbf{7 0 0}$ & $65.9 \pm 0.20$ & $79.2 \pm 0.20$ & $72.1 \pm 0.20$ \\
\hline $\mathbf{8 0 0}$ & $61.0 \pm 0.14$ & $70.0 \pm 0.22$ & $68.4 \pm 0.17$ \\
\hline $\mathbf{9 0 0}$ & $56.4 \pm 0.21$ & $62.7 \pm 0.23$ & $64.4 \pm 0.18$ \\
\hline $\mathbf{1 0 0 0}$ & $50.9 \pm 0.54$ & $58.5 \pm 0.28$ & $60.5 \pm 0.11$ \\
\hline
\end{tabular}

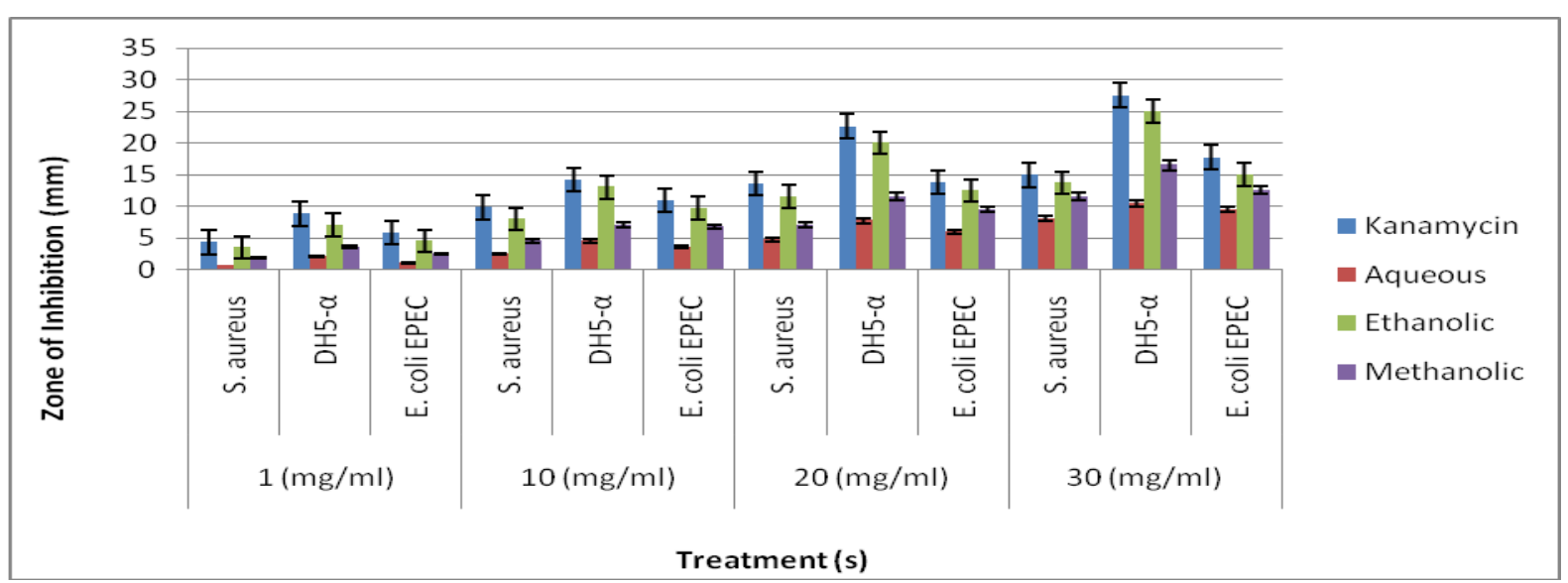

(A)

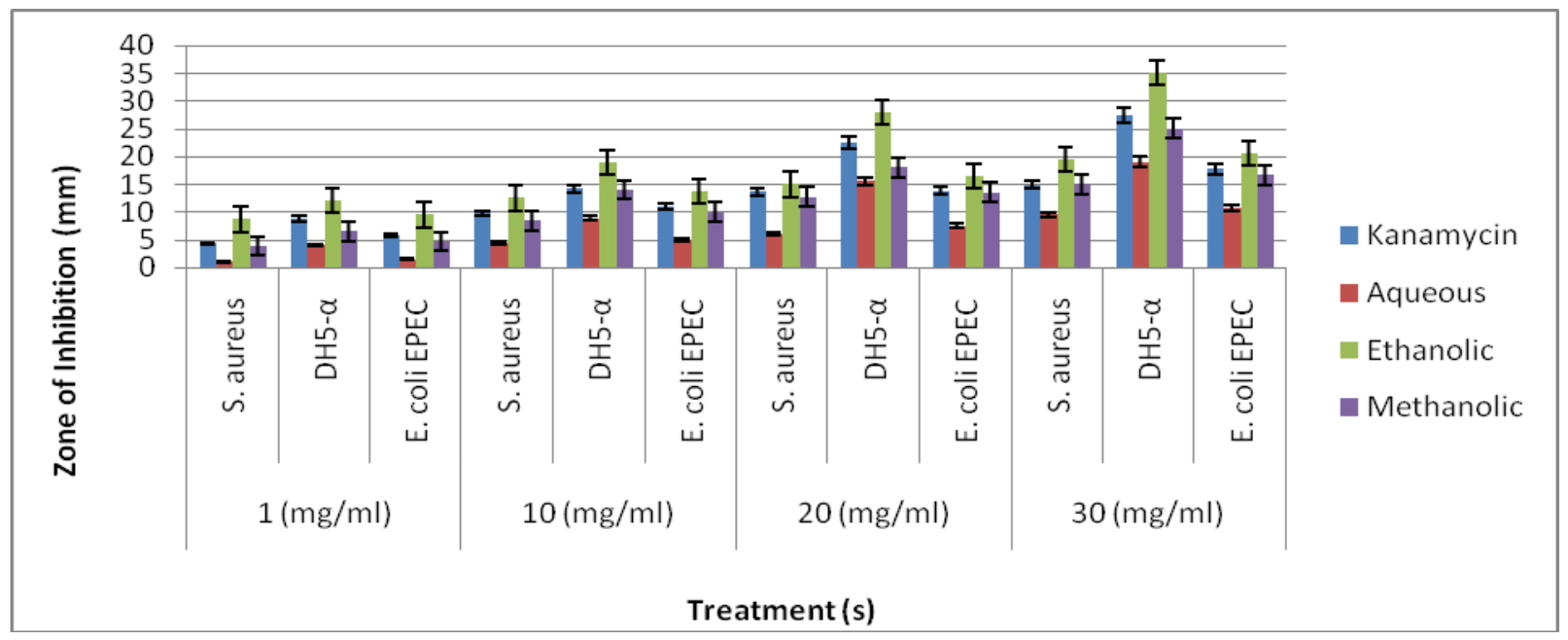

(B)

Figure.1 Zones of growth inhibition $(\mathrm{mm})$ of three bacterial strains in response to (A) Fresh and (B) Dried P. oleracea extracts at different concentrations 


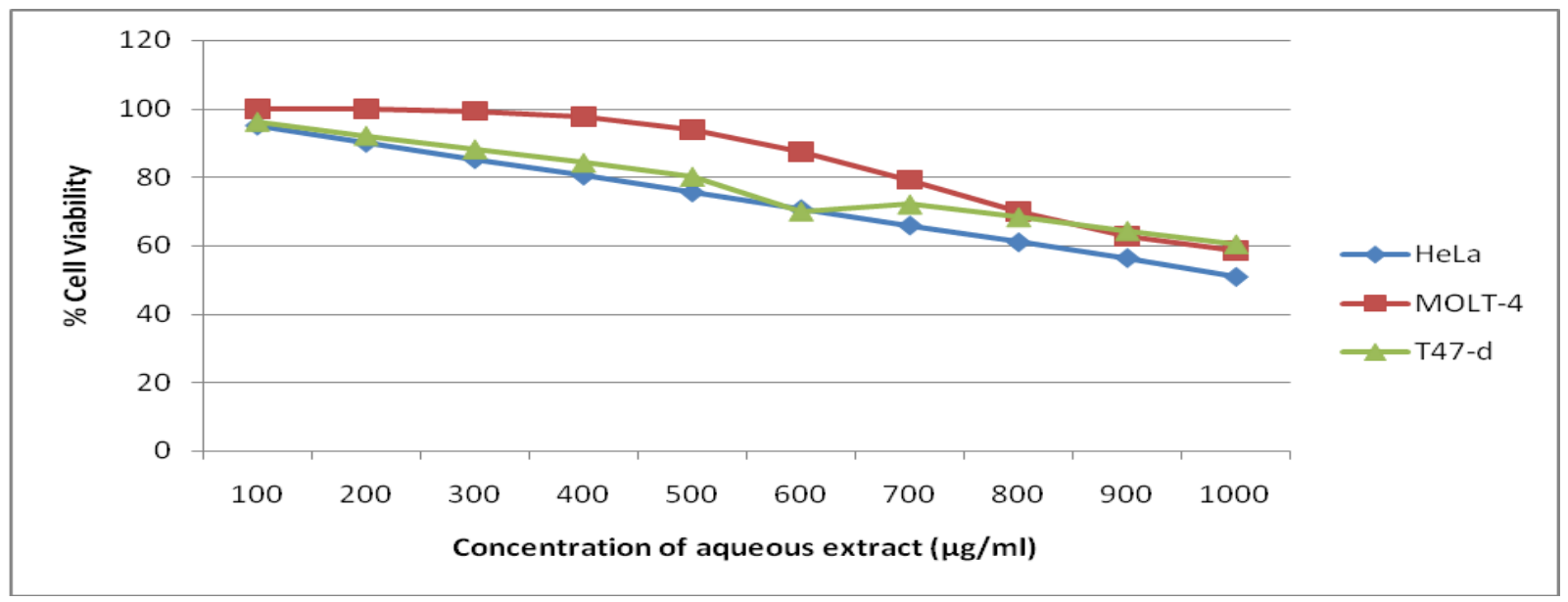

Figure.2 Relationship of percent cell viability of HeLa, MOLT-4 and T47-d cells with different concentrations of aqueous extracts (48hr)

It is suggested that the better antiproleferative property of aqueous extract of dried $P$. oleracea extract may be attributed to higher concentration of bioactive nutraceutical compounds present in it as compared to fresh samples (Lim et al., 2007). Thus from these results we suggest that aqueous extract of dried $P$. oleracea can be better exploited for its anticancer role and the study warrants more research in this direction.

From the current study it can be concluded that $P$. oleracea has an exceptionally high nutritional and nutraceutical value and has great potential especially in its dried form to be further exploited for its antimicrobial and anticancer properties.

\section{Acknowledgement}

Authors are highly thankful to Dr Fayaz Ahmad Malik, Principal Scientist, IIIM, Srinagar for his valuable support related to anticancer assays.

\section{References}

Abbasi AM, Shah AM, Khan MH, Mir A (2015). Wild edible vegetables of lesser Himalayas. J. Ethanobot. Nutraceut. Aspects, 1.
Abd El-Aziz HA, Sobhy MH, Ahmad KA, Abd El hameed AK, Rahman ZA and Hassan WA. (2014). Chemical and remedial effects of purslane (Portulaca oleracea) plant. Life Sci. J. 11(6), 31-42.

Al-Hasawi N A, Amine SA and Novotny L (2018). The In Vitro Anti-Proliferative Interaction of Flavonoid Quercetin and Toxic Metal Cadmium in the 1321N1 Human Astrocytoma Cell Line. Scientia Pharmaceut. 86(36), 1-13.

Amaral RG, Dos-Santos SA, Andrade LN, Severino $\mathrm{P}$ and Adriana Andrade Carvalho AA. (2020). Natural Products as Treatment against Cancer: A Historical and Current Vision. Clin. Oncol. 4, 1-5.

Association of Official Analytical Chemists (2000). Official Methods of Analysis. 7th ed. Washington DC, Arlington, Virginia, USA: Association of Official Analytical Chemists.

Bakkiyaraj S and Pandiyaraj S (2011). Evaluation of potential antimicrobial activity of some medicinal plants against common food-borne pathogenic microorganism. Int. J. Pharma. Biosci. 2(2)484- 491.

Chen T, Wang J, Li Y, Shen J, Zhao T, Zhang $H$ (2010). Sulfated modification and 
cytotoxicity of Portulaca oleracea L. polysaccharides. Glycoconjugate J. 27, 635-642

Chugh V, Mishra V, Dwivedi SV and Sharma KD (2019). Purslane (Portulaca oleracea $\mathrm{L}$.): An underutilized wonder plant with potential pharmacological value. The Pharm. Innov. J. 8(6), 236-246

Conti MV, Campanaro A, Coccetti P, DeGiuseppe R, Galimberti A, Labra M, Cena H (2019). Potential role of neglected and underutilized plant species in improving women's empowerment and nutrition in areas of sub-Saharan Afr. Nutr. Rev. 77(11), 817-828.

Dhole JA, Dhole NA, Lone KD and Bodke SS (2011). Preliminary Phytochemical Analysis and Antimicrobial Activity of Some Weeds collected from Marathwada Region. J. Res. Biol. 1, 19-23.

Dugawale TP, Khanwelkar CC and Durgawale PP(2019). Quantitative estimation of total phenolic content of two species of Portulaca obtained by using microwave assisted extraction and its validation. Int. J. Pharm. Sci. and Res. 10(3): 1269-1274

Durgawale PP, Patil MN, Joshi SA, Korabu KS, Datkhile KD (2019). Studies on phytoconstituents, in vitro antioxidant, antibacterial, antiparasitic, antimicrobial, and anticancer potential of medicinal plant Lasiosiphon eriocephalus decne (Family: Thymelaeaceae). J. Natur. Sci. Biol. Med.10 (1), 38-47.

Ebert AW(2014).Potential of underutilized traditional vegetables and legume crops to contribute to food and nutritional insecurity, income and more sustainable production systems. Sustainability. 6, 319-335.

El Kashef RKH, Soliman AS, Hassan
HMM and Abd-Elhak NA (2018).Evaluation of total phenolic content and antioxidant activity of different solvent extracts of Egyptian purslane leaves. Curr. Sci. Int. 7(4), 616-623

EL-Hadidy GSM (2014). Chemical, technological and biological studies on mulberry leaves and purslane in Egypt. Ph.D Thesis, FacAgric, Mansoura University, Egypt.

Erdem, Aslan S, Nabavi SF, Orhan IE, Maria Daglia, Morteza Izadi, and Nabavi SM (2015). Blessings in Disguise: A Review of Phytochemical Composition and Antimicrobial Activity of Plants Belonging to the Genus Eryngium. DARU J. Pharm. Sci.23 (1), 1-22.

Fatima A, Laila O, Murtaza I and Masoodi K. (2020). Nutraceutical Composition and Anti-Cancerous Potential of an Unexplored Herb Asplenium ceterach from Kashmir Region, Ind. J. Pure App. Biosci. 8(2), 289-297.

Gonmei Z and Toteja GS (2018). Micronutrient status of Indian population. Ind. J. Medical Res. 148(5), 511-521.

Gupta S, Gowri SB, Lakshmi JA, (2013). Retention of nutrients in green leafy vegetables on dehydration. J. Food Sci. Technol. 50(5), 918-925.

Hassan A (2014). Chemical and remedial effects of purslane (portulaca oleracea) plant. Life Sci. J.11, 31-42.

Joshi P and Mehta D (2010). Effect of dehydration on the nutritive value of drumstick leaves. J. Metabolomics and Syst. Biol, 1(1), 5-9.

Khaled, MY, Sayed MM (2014). Effect of drying chemical methods on the antioxidant capacity, color and phytochemicals of Portulaca oleracea L. J. Nutr. Food Sci. 4(6), 2155-9600.

Khameneh, B., Iranshahy, M., Soheili, V, 
Bazzaz BSF (2019). Review on plant antimicrobials: a mechanistic viewpoint. Antimicro. Resist. Infect. Cont.8(118), 1-28

Khan MI, Harsha PS, Giridhar P. and Ravishankar GA (2011). Pigment identification, antioxidant activity and nutrient composition of Tinospora cordifolia (Willd.) Miers ex Hook. f and Thoms fruit. Int. J. Food Sci. Nutr, 62, 239-249.

Khanam B, Begum W and Tipo FA (2019). Pharmacological profile, phytoconstituents, and traditional uses of Khurfa (Portulaca oleracea L.): Unani perspective. The Pharma. Innov. J. 8(4), 367-372.

Kour S, Bakshi P, Sharma A, Wali V, Jasrotia A, Kumari S (2018). Strategies on Conservation, Improvement and Utilization of Underutilized Fruit Crops. Int. J. Curr. Microbiol. Appl. Sci.7 (3), 638-650.

Lallianrawna S, Muthukumaran R, Ralte V, Gurusubramanian G, Kumar NS(2013). Determination of total phenolic content, total flavonoid content and total antioxidant capacity of Ageratinaadenophora (Spreng.) King \& H. Rob. Sci. vision, 13, 149156.

Lim DY, Jeong Y, Tyner AL and Park JH (2007). American. J. Physiol. Gastrointestinal. Liver Physiol.292, 66-75.

Lim YY and Quah EPL (2007), Antioxidant properties of different cultivars of Portulaca oleracea, Food Chem.103, 734-740.

Londonkar R and Nayaka HB (2011). Phytochemical and antimicrobial activities of Portulaca oleracea. J. Pharm. Res. 4(10), 3553-3555.

Malick CP and Singh MB (1980). Plant Enzymology and Histoenzymology. Kalyani publications, New Delhi,
India.

Mango N, Makate C, Mapemba L and Sopo M (2018). The role of crop diversification in improving household food security in central Malawi. Agric. and Food Secur.7, 1-10

Martínez-Las Heras R, Heredia A, Castelló ML, Andrés A (2014). Influence of drying method and extraction variables on the antioxidant properties of persimmon leaves. J. Food Biosci, $6,1-8$.

Miles RS and Amyes SG (1996). Laboratory Control of Antimicrobial Therapy. In: Mackie and McCartney Practical Medical Microbiology, Collee JG, Fraser AG, Marmion BP and Simmons A (Eds.). 14th Edn., Churchill Livingstone, New York, pp. 151-178.

Nabi S, Rather SA, Nabi B and Qaisar KN (2017). Botanicals and their use with special reference to J\&K. Int. J. Sci. Env.6 (5), $3174-3180$

Nagata M and Yamashita I (1992). Simple method for simultaneous determination of chlorophyll and carotenoids in tomato fruit. The Jap. Soc. Food Sci. Technol. 39(10), 925928.

Olsen K, Arscott S, and Tanumihardjo AS (2015). Carotenoid profiles of dried herbs, water infusions and alcoholic tinctures of Calendula flower and Catnip, Dandelion, Stinging nettle and Violet leaves. Nat. Prod. Chem. and Res,3:1.

Panche A, Diwan A, ChandraS (2016). Flavonoids: an overview, J. Nutr. Sci. Vitaminol.5, 47.

Peng, S, Dai W, Yu H, Wang Y, Wang X and Sun S (2014). Antibacterial activity of aqueous and ethanolic extracts of Portulaca oleracea L. and Taraxacum mongolicum against pathogenic bacteria of cow mastitis. 
2014. Int.J. Appl. Res. Vet. Medic.12(3), 210-214.

Qiu Z, Xiaoxuan W, Jianchang G, Yanmei G, Zejun H, Yongchen Du (2016). The tomato Hoffman's Anthocyaninless gene encodes a bHLH transcription factor involved in anthocyanin biosynthesis that is developmentally regulated and induced by low temperatures. Plos One11(3).

Ranganna S (1997). Handboor of Analysis And Quality Control for Fruits and Vegetable Products. 2nd ed., Tata Mac Graw Hill Publication Co., New Delhi. pp.112.

Rehman and Adnan M (2018). Nutritional potential of Pakistani medicinal plants and their contribution to human health in times of climate change and food insecurity. Pak. J. Bot. 50(1), 287-300.

Sadasivam S, Theymoli B (1987) In: Practical Manual Biochemistry, Tamil Nadu Agricultural University, Coimbatore pp. 14

Silva Rand Carvalho IS (2014). In vitro Antioxidant Activity, Phenolic Compounds and Protective Effect against DNA Damage Provided by Leaves, Stems and Flowers of Portulaca oleracea (Purslane) Nat. Prod. Comm. 9 (1), 45-50

Tan GCS, Wong KM, Pearle-Wong GQ, Yeo SL, Yeap SK, Yiap BC and Chon hz (2013). In vitro cytotoxic and antiproliferative effects of Portulaca oleracea methanol extract on breast, cervical, colon and nasopharyngeal cancerous cell lines. Sains Malays.
42(7), 927-935.

Thimmaiah SK. (1999). Standards methods of bio-chemical analysis. New-Delhi, India, Kalyani publishers.

USDA national nutrient data, 2016 (https://www.nal.usda.gov/fnic/usdanutrient-data-laboratory)

Wasnik DD and Tumane PM (2014). Preliminary phytochemical screening and evaluation of antibacterial activity of Portulaca oleracea L. against multiple drug resistant (MDR) pathogens isolated from clinical specimen. World. J. Pharmaceut. Res. 3(10), 920-931.

World Heal organization: Lack of new antibiotics threatens global efforts to contain drug-resistant infections, 2020 (https://www.who.int/newsroom/detail/17-01-2020-lack-of-newantibiotics-threatens-global-efforts-tocontain-drug-resistant-infections)

World Health Organisation report on cancer, 2020. Setting priorities, investing wisely and providing care for all.1160

Youssef KM, Mokhtar SM (2014) Effect of Drying Methods on the Antioxidant Capacity, Color and Phytochemicals of Portulaca oleracea L. Leaves. J. Nutr. Food Sci. 4, 1-6

Zakaria AS and Hazha JH (2013). Cytogenetic toxicity effects of local purslane (Portulaca oleracea) leaf crude extracts on normal and cancer cell lines in vitro. Int.J. Drug Discov. 5(1), 173-180.

\section{How to cite this article:}

Imtiyaz Murtaza, Navreen Rashid, Omi Laila, Nisar Ahmad Ganie and Younus Wani. M. 2020. Anti-cancer and Anti-microbial Potential of Nutraceutical Rich Under utilized Herb Portulaca oleracea from Kashmir Region. Int.J.Curr.Microbiol.App.Sci. 9(09): 3496-3508. doi: https://doi.org/10.20546/ijcmas.2020.909.434 